\title{
CODIGOFAGIA EN LOS TEXTOS VISUALES DE LA DESCRIPCIÓN DE LA CIUDAD Y PROVINCIA DE TLAXCALA (1584)
}

\author{
CODEPHAGOCYTOSIS IN THE VISUAL TEXTS OF THE DESCRIPTION \\ OF THE CITY AND PROVINCE OF TLAXCALA (1584)
}

AlejANDRO VIVEROSA

La Descripción de la ciudad y provincia de Tlaxcala (1584), Diego Muñoz Camargo, es un claro ejemplo de la interrelación de horizontes culturales europeos e indígenas durante la primera etapa de la colonización americana en Nueva España. Consta de 156 figuras o textos visuales en los cuales se canaliza un discurso alternativo y correlativo que vectoriza el sentido del texto alfabético. El concepto de "codigofagia" permite profundizar en la transferencia, el agenciamiento y la apropiación de conocimientos e imaginarios en una dimensión ontológico-semiótica y nos permite comprender e interpretar algunos de los textos visuales de la Descripción.

Palabras clave: crónicas de indios, codigofagia, textos visuales, Diego Muñoz Camargo, Tlaxcala.

Diego Muñoz Camargo's Description of the City and Province of Tlaxcala (1584) is a prime example of the interrelations between European and Indigenous cultural horizons during the first step of colonization of New Spain. The Description has 156 images or visual texts conveying an alternative, correlative discourse that vectorizes the meaning of the alphabetic text it accompanies. Through the concept of code-phagocytosis this article will unpack the transfer, composition and the appropriation of knowledge and imaginaries on a semiotic-ontological level. More specifically, the concept of code-phagocytosis will be used in the aim of understanding and interpreting a series of some of the visual texts from the Description.

Keywords: Indian chronicles, code-phagocytosis, visual texts, Diego Muñoz Camargo, Tlaxcala
“Quién puede entender verdaderamente el rostro de los indios? Es un solo rostro que viene de muy lejos, que viene de edades inexpresables, pero de las que aún

se guarda memoria. Los indios se quedan callados, pensando, aunque es posible que no piensen en nada. Siempre parece que han perdido algo muy profundo, que les pertenecía por entero y que no volverán a recuperar jamás. Y buscan ese algo, lo aguardan”

(Revueltas 2016: 55).

La obra de Diego Muñoz Camargo titulada Descripción de la ciudad y provincia de Tlaxcala (1584) es un claro ejemplo de la interrelación de conocimientos e imaginarios europeos e indígenas durante la primera etapa de la colonización americana en Nueva España. La Descripción posee 156 figuras, imágenes o textos visuales. ${ }^{1}$ Estos configuran un discurso alternativo y, en cierto sentido, correlativo al que se presenta en el texto alfabético. Proponemos utilizar el concepto de codigofagia -acuñado por Bolívar Echeverría - para comprender e interpretar los textos visuales de la Descripción, profundizando en las imbricaciones entre los códigos culturales europeos e indígenas y sus concomitantes vectorizaciones de sentido.

A Alejandro Viveros Espinosa. Resultado del proyecto CONICYT-FONDECYT Iniciación № 11160012, "Convivencia interétnica y traducción cultural. Aproximaciones sobre el contenido filosófico-político de las crónicas de indios en el mundo cultural novohispano (1576-1650)”, Universidad de Chile. Pasaje Marco Aurelio 720, Maipú, Santiago, Chile, E-mail: aviveros@u.uchile.cl 
El concepto de codigofagia profundiza en una dimensión ontológico-semiótica. En términos generales, Echeverría propone una semiosis comunicativa en conflicto entre códigos culturales, tanto a nivel visual como alfabético. Esto significa llevar a cabo un ejercicio de análisis e interpretación que considera la codigofagia como una plataforma conceptual para la reflexión crítica en torno a esta particular obra de Diego Muñoz Camargo. Con este objetivo, dividiremos nuestro acercamiento en tres movimientos. El primero se refiere a las crónicas de indios y al posicionamiento de la codigofagia como un concepto útil para interpretar la Descripción. Con el segundo se desarrolla una lectura codigofágica sobre la Descripción, sus contenidos, sus contextos de producción y circulación, para luego analizar los motivos presentes en una selección de ocho textos visuales (ver anexos). Reconoceremos en ellos, principalmente, los modos de transferencia y apropiación de códigos culturales. Finalmente, un tercer movimiento conclusivo desarrolla una lectura de la Descripción que permite relevar un horizonte de preguntas y una propuesta civilizatoria en construcción.

\section{EN TORNO A LAS CRÓNICAS DE INDIOS Y LA NOCIÓN DE CODIGOFAGIA}

Posicionamos las propuestas acerca de la historiografía indiana como campo de estudio sobre la América colonial, reconociendo la heterogeneidad de materiales y textos culturales (Bachmann-Medick 2016). Así también, reconocemos la necesidad de análisis comparativos del asentamiento de las complejas interrelaciones (principalmente de intertextualidad) como axioma metodológico en el estudio de aquel "arco increíble de textos en perspectiva y elaboración verbal, que permiten análisis comparativos de diferente dimensión y objetivo" (Stoll 2010: 1281).

Queremos volver sobre la historiografía indiana y sus materiales escriturales atendiendo al rendimiento de estos textos en diversas direcciones e interpretaciones. En ese sentido es posible integrar el concepto de crónica mestiza acuñado por Martin Lienhard, porque nos abre a la inclusión de elementos directamente relacionados con una dimensión histórico-literaria en las producciones escriturales realizadas por los indios durante la colonización americana. A través de las crónicas mestizas, funcionalizadas como pivote con- ceptual, podemos elaborar un ejercicio teórico-crítico relativo a un discurso identitario en construcción que contiene elementos histórico-literarios dispuestos a ser pensados y utilizados de forma no dogmática y en apertura a nuevos horizontes de pregunta, configurando "las premisas de una nueva conciencia global, histórica, política y cultural" (Lienhard 1983: 107).

Así también, es posible incorporar algunas reflexiones de Bolívar Echeverría con respecto a dos conceptos que, de acuerdo a nuestros intereses, son fundamentales e interrelacionados. Nos referimos al mestizaje cultural y a la codigofagia:

\begin{abstract}
El mestizaje cultural ha consistido en una "código-fagia" practicada por el código cultural de los dominadores sobre los restos del código cultural de los dominados. Ha sido un proceso en que el devorador ha debido muchas veces transformarse radicalmente para absorber de manera adecuada la substancia devorada; en el que la identidad de los vencedores ha tenido que jugarse su propia existencia intentando apropiarse de la de los vencidos (Echeverría 2001: 63).
\end{abstract}

Echeverría se refiere al proceso de mestizaje cultural como un "devorar" entre códigos culturales. Es ahí donde, de forma codigofágica se construye un tipo de subjetividad culturalmente tensionada, liminal, en movimiento, que apropia y re-direcciona en sentido amplio los horizontes de comprensión e interpretación relativos a la construcción de aquellas subjetividades alternas y mestizas. Esto implica plantear nuevamente la pregunta por la identidad cultural.

\footnotetext{
Si la identidad cultural deja de ser concebida como una sustancia y es vista más bien como un "estado de código" -como una peculiar configuración transitoria de la subcodificación que vuelve usable, "hablable", dicho código-, entonces, esa "identidad" puede mostrarse también como una realidad evanescente, como una entidad histórica que, al mismo tiempo que determina los comportamientos de los sujetos que la usan o "hablan", está siendo hecha, transformada, modificada por ellos (Echeverría 2005: 31).
}

El abandono de una perspectiva sustancialista sobre la identidad cultural en favor de una lectura semiótica, aleja a Echeverría del esencialismo culturalista latinoamericano. En consecuencia, la noción de "estado de código" implica una subjetividad evanescente aplicable en nuestro estudio. La identidad cultural (código cultural) se juega en sus posibilidades para devorar y ser devorado.

Luego, la realidad evanescente conduce a una transformación desde la cual las identidades culturales están 
siendo constantemente re-construidas. Echeverría apunta al modo de construcción y actualización de los códigos en virtud de una nueva instauración de posibilidades sémicas. Asimismo, evita el formalismo atribuyendo a los códigos, a sus significaciones y resignificaciones, una experiencia histórica (historicidad). Pero ¿quiénes y cómo usan y hablan esos códigos?, ¿quiénes y cómo los transforman y reconstruyen?

\begin{abstract}
Jugando a ser europeos, no copiando las cosas o los usos europeos, sino imitando el ser europeo, simulando ser ellos mismos europeos, es decir, repitiendo o "poniendo en escena" lo europeo, los indios asimilados montaron una muy peculiar representación de lo europeo. En una representación o imitación que en un momento dado, asombrosamente, había dejado de ser tal y pasado a ser una realidad o un original: en el momento mismo en que, ya transformados, los indios se percataron de que se trataba de una representación que ellos ya no podían suspender o detener y de la que, por lo tanto, ellos mismos ya no podían salir; era una "puesta en escena absoluta", que había transformado el teatro en donde tenía lugar, permutando la realidad de la platea con la del escenario (Echeverría 2010: 191).
\end{abstract}

La clave que entrega Echeverría está en aquel poner en escena llevado a cabo por los indios, en el cual se fraguó su supervivencia cultural e identitaria. Finalmente, como representación o imitación de un mundo desconocido, como una imitación reconfigurada por sus propios y reinventados horizontes de comprensión, alterada en virtud de las circunstancias y los contextos, y que se construye permutando "la realidad de la platea con la del escenario".

Entre aquellos indios que se vieron obligados a ponerse en escena y desplegar los códigos culturales europeos, remarcamos un grupo especial, a saber, los indios que escriben y que han sido catalogados de diferentes maneras: humanistas y letrados (LeónPortilla 1964, 1966; Garibay 2007; Romero 2011), ladinos (Adorno 1992, Bernand 2001, Cornejo Polar 2011), zonas de contacto (Pratt 1991. Cortés \& Zamora 2016), traductores culturales (Navarrete 2007b, Payàs 2010, Añón 2012, Valdeón 2014, Richter 2015), passeurs (O'Phelan \& Salazar 2005), o bien como intelectuales indígenas (Ramos \& Yannakakis 2014). Nos referimos a aquellos que aprendieron y usaron la escritura y que, a través del código alfabético europeo como vehículo, lograron sobrevivir, negociar y reconducir su experiencia histórica. Esto acontece porque es una escritura que pretende hacer notar que la historia del indio puede ser escrita también por uno de ellos.
Buscamos reconocer cómo los llamados indios, escribiendo y traduciendo, llevan a cabo aquella puesta en escena que deviene en una construcción históricoliteraria única. Nuestra perspectiva busca pensar con Echeverría y poner sus ideas en movimiento, especialmente en y a través de modalidades fronterizas, liminales, alternativas al sujeto moderno-occidental. Estas catalizan y redireccionan discursos y problemas de profundo carácter semiótico-ontológico. Aquí se configura una escritura que intenta dialogar entre modos europeos de articulación discursiva muchas veces relativa a la tradición bíblica, clásica o humanista, en conjunto con aquellas fuentes otras, principalmente relacionadas con las tradiciones orales, con la escritura pictográfica (Gruzinski 2004: 15-76) presente en los códices y con experiencias polisensuales. ${ }^{2}$

Hablamos de una escritura codigofágica en cuanto una modulación de la codigofagia (Echeverría 2001, 2005); empero, esta no se reduce a la escritura sino que en ella se re-direcciona. Una escritura codigofágica es también un ejercicio de recolección de fragmentos discursivos o sistemas de dispersión fragmentarios (Ortega 2011), en el que efectivamente se canaliza una elección civilizatoria (Echeverría 2001), que concede un espacio de enunciación a subjetividades alternativas profundizando en los conflictos y tensiones de su reconstrucción identitaria y cultural. Así, el valor de la escritura codigofágica es operacional. Son los modos de recolección de los fragmentos discursivos en un movimiento de constante reconfiguración conflictiva de códigos. Procuraremos aplicar este modo de aproximación, en tanto escritura codigofágica, a una crónica en particular, poco conocida, como es la Descripción de la ciudad y provincia de Tlaxcala de las Indias y del Mar Océano para el buen gobierno y ennoblecimiento dellas, mandada hacer por la Sacra Católica Real Majestad del rey Don Felipe nuestro señor, de Diego Muñoz Camargo.

\section{LA DESCRIPCIÓNY SUS TEXTOS VISUALES: UNA LECTURA CODIGOFÁGICA}

¿Quién es Diego Muñoz Camargo? Charles Gibson (1950) enuncia la autoría e identidad de Diego Muñoz Camargo (1528-1599), ulteriormente funcionalizadas en virtud de su condición de mestizo emparentado con familias de abolengo indígena y de su condición 
bilingüe (náhuatl y español). Queremos relevar algunos elementos biográficos que pueden colaborar en nuestra indagación. Diego Muñoz Camargo parece haber gozado de lugares importantes tanto en asuntos oficiales como en negocios personales, principalmente asociados a la ganadería y la producción de sal (Gibson 1950, Hernández 2011, Daneri 2016). Destaca también su cercanía con el orden colonial, y con ello la confianza de los gobernantes tlaxcaltecas. Aquí remarcamos la propuesta de Thomas Ward (2001), quien identifica a Muñoz Camargo dentro del proyecto de construcción de nación o república en un trayecto que abarca el cruce y la configuración de horizontes y procesos de etnicidad desde una comprensión histórica.

Nuevamente, ¿quién es Diego Muñoz Camargo? Podemos perseguir esta pregunta en virtud de su producción histórico-literaria. Dos obras componen el centro de la producción de Muñoz Camargo: la Descripción (1584) y la Historia de Tlaxcala (1590). Ambas encadenan un relato específico e interconectado. Quizá la Historia es una obra mucho mejor lograda al momento de reconstruir los eventos relativos a la provincia de Tlaxcala. Lo que se explica, precisamente, porque es una producción posterior a la Descripción. En cierto sentido, en la Historia se evidencia un estilo y una posición de enunciación mucho más lograda en cuanto a la composición de un relato sobre la historicidad de aquellas tierras. Aun cuando queremos pensar la Descripción y la Historia como textos entremezclados, creemos que se trata de experiencias diferentes relativas a un mismo y único objetivo: dar a conocer los avatares de esas tierras que, a la luz de su participación en la conquista y en el orden colonial, merecen un trato especial.

Por comisión de Alonso de Nava, alcalde mayor de Tlaxcala, alrededor de 1580 Diego Muñoz Camargo comienza a escribir su Descripción de la ciudad y provincia de Tlaxcala, la cual fue finalizada cerca de $1584 \mathrm{y}$ luego entregada personalmente al rey Felipe II durante la embajada de 1585. La obra integró la biblioteca de El Escorial y actualmente se encuentra en la Universidad de Glasgow y se conoce como el Manuscrito de Glasgow. Entre los trabajos críticos en torno al Manuscrito, utilizaremos la versión paleográfica de René Acuña (1986) y la versión facsimilar también de Acuña (1981). ${ }^{3}$

La Descripción como tal es una obra compleja en su estilo y en su objetivo. Es un texto escrito de forma continua. Se inicia con la "Instrucción y Memoria", que consta de cincuenta preguntas, luego presenta una de- dicatoria al rey Felipe ir y una aclaración de intenciones relativas a la redacción. A continuación, la obra se divide en dos libros, el primero contiene veinte capítulos en prosa; el segundo, algo más caótico, incluye la "cuenta de los años de los indios", un "calendario índico de fray Francisco de las Navas", una explicación "de los años" y "de los bisiestos", junto con una aclaración de las cuentas de "días, meses y años" cristianos verificados en la "Cuenta de Antonio de Guevara", a ello agrega un capítulo sobre la "fauna y la flora de Tlaxcala", para finalizar con siete capítulos dedicados a las "cabeceras de Ocotelulco, Quiyahuitztlán, Tepeticpa y Tizatlán", a "capitanes famosos", "divisas y armas", y un último apartado dedicado a aquellos asuntos que no alcanzaron a ser tratados en la obra.

La Descripción debe cumplir con los estándares de una relación geográfica siguiendo la "Instrucción y Memoria” (Muñoz Camargo 2000 [1584]: 27-32), que remite a una descripción territorial focalizada grosso modo tanto en ríos y montañas, en asentamientos y poblaciones, como en las potencialidades económicas y políticas. Frente a este escenario, Muñoz Camargo interviene proporcionando una perspectiva mucho más específica. En la composición del texto alfabético de la Descripción podemos reconocer que hay un orden propio y una desproporción en el tratamiento de algunos temas, como también una intención por historizar más que meramente informar. Hay en la Descripción un estilo heterogéneo y aglutinante que procura referir a las cuatro cabeceras de Tlaxcala, describiendo a veces repetitivamente la información correspondiente a cada una.

Asimismo, despliega una perspectiva históricoliteraria proclive a responder a lo largo del texto a las cincuenta preguntas con una particular especificidad. Hay momentos de claridad y de un estilo reflexivo sobre los modos de gobierno y decisiones políticas desarrolladas por los naturales de Tlaxcala. Entre ellos destacamos aquel relativo a la respuesta que entregan las cuatro cabeceras frente a la exigencia de rendición por parte de los mexicas. Sostiene sobre ello: "Señores muy poderosos, Tlaxcala no [o]s debe vasallaje ni, desde que salieron de las Siete Cuevas, jamás reconocieron con tributo ni pecho a ningún rey ni principal del mundo, porque siempre han conservado su libertad" (Muñoz Camargo 2000 [1584]: 180). Esta postura conduce al conflicto entre Tlaxcala y la Triple Alianza, en el cual se desarrolla un relato de forma propedéutica a fin de explicar la posición política de Tlaxcala en tiempos precortesanos. 
Y, como hubiesen los mexicanos tenochcas sujetado la mayor parte deste nuevo mundo y que [su señor] no tuviese ya que ganar desde la Mar del Sur a la del norte, y todo lo que tuviese por suyo, procuró muy a su salvo tomar la provincia de Tlaxcalla y sujetarla, así como había hecho a las demás. Y ansí, los mexicanos, con ánimo denodado, les dieron tantos recuentros y escaramuzas, hasta que los vinieron a acorralar dentro de pocos años en sus $\mathrm{p}[$ ro]pias tierras y provincia, donde los tuvieron cercados más de 60 años, necesitándolos de todo cuanto humanam[en] te los pudieron necesitar, por no tenían algodón con que se vestir, oro ni plata con que se adornar, ni plumería verde de otras colores para sus galas, que es la que más estimaban para sus divi[s] as y plumajes, ni cacao para beber, ni sal para poder comer (Muñoz Camargo 2000 [1584]: 180-181).

Más allá de los sesenta años de asedio mexica, los tlaxcaltecas -en voz de Muñoz Camargo- sufren las consecuencias de ser enemigos necesarios en una comprensión político-sacrificial de la guerra (López Austin 2014). Desde ahí se explica claramente la constante belicosidad hacia Tlaxcala. Entonces, la guerra funciona como asunto político-religioso que genera la necesidad de enemigos que permitan continuar con las prácticas religioso-sacrificiales $y$, ciertamente, con la formación de nuevos guerreros. Tlaxcala es el productor de enemigos y tiene ese lugar dentro de las guerras religiosas-sacrificiales (Domínguez 2013).

La Descripción incorpora también dos ruedas calendáricas junto con explicaciones de las mismas, que responden al calendario índico de fray Francisco de Navas. En la primera se incluyen días, semanas, meses y años, y en la segunda, los meses según el calendario lunar de veinte días. Cada una contiene anotaciones e indicaciones detalladas y aclarativas respecto de los modos en que los naturales medían el tiempo (Muñoz Camargo 2000 [1584]: 222-233). El interés por el tiempo como problema filosófico es central para el mundo cultural mesoamericano. Nancy Farriss (1985) problematiza este asunto a partir de una dicotomía entre una comprensión estacionaria y cíclica, y una comprensión lineal o teleológica, en las que se juegan oposiciones complementarias, específicamente en la intervención del horizonte cultural cristiano presente en las crónicas o en relatos producidos por indios coloniales del área maya. Sin embargo, es posible establecer que la Descripción se concentra más bien en sintonizar o bien acomodar el problema del tiempo a una explicación cristiana. El interés por el tiempo en la Descripción pone en escena un gesto codigofágico (Echeverría 2001, 2005), pues según la explicación del calendario cristiano, se negocia con modalidades de la comprensión nahua del tiempo. El detalle en la explicación del calendario índico de fray Francisco de Navas y las celebraciones asociadas a días específicos son ejemplos de ello (Muñoz Camargo 2000 [1584]: 222-233).

En consecuencia, la Descripción nos abre a reconocer en ella los elementos en negociación y transferencia que se muestran en dos códigos interrelacionados, uno alfabético y otro visual. Los tópicos tratados en el código alfabético, como hemos indicado, responden en amplios rangos al cuestionario ("Instrucción y Memoria"). A ello agrega Muñoz Camargo 156 figuras o textos visuales, muchas de ellas intervenidas con elementos alfabéticos explicativos. Cada una de las figuras ocupa una página dibujada a pluma en tinta negra sin colorear; 80 de ellas coinciden -con algunas variantes- con las pinturas del célebre Lienzo de Tlaxcala. ${ }^{4}$

Siguiendo lo señalado por Acuña (1981) en el Estudio preliminar de su edición facsimilar, los 156 textos visuales de la Descripción se pueden clasificar en cuatro series. En breve, podemos indicar que la primera serie (textos visuales 1-19) está dedicada a las cuatro cabeceras de Tlaxcala, la predicación evangélica franciscana, los templos y los juegos antiguos, el ajusticiamiento de algunos caciques, el modelo habitacional de Xicoténcatl, la plaza y el monasterio de Tlaxcala y las provincias y reyes que conquistó Cortés antes de su llegada a Tlaxcala. "Se puede observar hasta aquí que la narración pictórica no sigue orden alguno" (Acuña 1981:34). La segunda serie (textos visuales 20-25) muestra imágenes de Cortés, Colón, Pizarro y sus ofrendas a Carlos v y Felipe II. Se trata de "escenas alegóricas sueltas, relacionadas unas con otras por el gran tema del descubrimiento y conquista del Nuevo Mundo. Se corresponden con las que dice Muñoz Camargo que había pintadas en la sala y Audiencia capitulares de la ciudad de Tlaxcala" (Acuña 1981: 34).

La tercera serie (textos visuales 26-75) se refiere a las batallas que los tlaxcaltecas libraron en alianza con los españoles en la conquista de México-Tenochtitlán. Ahí podemos reconocer que los textos visuales tampoco se ajustan a una cronología estricta. La cuarta serie (textos visuales 76-156) aborda el lugar de los tlaxcaltecas en la conquista y colonización de otras provincias y latitudes, a saber, las provincias de Pánuco, del México occidental, zonas específicas de Centroamérica (principalmente Guatemala, El Salvador y Nicaragua) y la provincia de Oaxaca, finalizando todo en "Cipolla", con la entrada que hizo Franco Vázquez de Coronado en tiempos de don 
Antonio de Mendoza. En rigor, la historia de conquista y colonización de Nueva España relatada visualmente por Muñoz Camargo se extiende desde 1519 hasta 1542.

Sin embargo, queremos profundizar en la Descripción y escuchar la voz tlaxcalteca como leal súbdito y merecedor de fueros por los servicios prestados, pero también como propuesta política de reconocimiento y autonomía. Para ello utilizaremos ocho figuras que nos permiten indagar en la propuesta de Muñoz Camargo y que dividiremos en tres temáticas. En la primera se alude a la ciudad de Tlaxcala. En la segunda, a la Malinche y la matanza de Cholula. La tercera retoma cinco textos visuales o figuras relacionadas con las guerras y conquistas de españoles y tlaxcaltecas contra otros indios en diferentes latitudes. En estas figuras es posible reconocer claramente las imbricaciones iconográficas propias en fricción y correlación con la tradición de modelos europeos. Por lo tanto, lo que buscamos relevar es el sentido de esta labor de traducción cultural como un relato que construye una posición de enunciación específica y constitutiva de un proyecto civilizatorio indio, tlaxcalteca, en desarrollo, dentro del orden colonial novohispano.

\section{La ciudad de Tlaxcala}

La idea de ciudad o civilidad es central en el relato de Diego Muñoz Camargo. Ciertamente, la construcción de una urbe con características europeas es fundamental, porque permite considerar cómo los propios tlaxcaltecas delinean su modo de vida a partir del espacio, esta vez intervenido por un horizonte civilizatorio distinto. La construcción de la ciudad de Tlaxcala es parte del proyecto colonial hispano que procura reunir a las cabeceras de Tlaxcala en torno a una urbe con diseño europeo y sus instituciones concomitantes (Martínez 2008: 135-196).

En los textos visuales presentes en la Descripción y referidos a la ciudad de Tlaxcala se distingue la distribución de las instituciones alrededor de la plaza principal (fig. 1): casas de los alcaldes mayores, caballerizas, carnicerías, mesón, cárcel, casas reales, fuente y picota. Asimismo, el monasterio franciscano de Nuestra Señora de la Asunción de Tlaxcala (fig. 2), ubicado en lo alto de la ciudad, y que Muñoz Camargo indica como "el sitio del monasterio de la ciudad de Tlaxcala", con detalles que todavía podemos admirar en la actualidad. En ambos textos visuales la disposición urbanística (el damero) es evidente.
La lectura de Ángel Rama (2004) sobre una ciudad ordenada/letrada es siempre útil. Sin embargo, podemos agregar que la ciudad de Tlaxcala, en función de ese ejercicio civilizatorio, separa espacialmente el poder político (fig. 1) y el poder religioso (fig. 2). Cecilia Gutiérrez (1990) analiza la configuración de la ciudad desde su fundación, trazo, repartición de solares, junto con la construcción de los primeros edificios civiles, a partir del dibujo de la plaza presente en la Descripción y en las actas de cabildo de Tlaxcala. Gutiérrez (1997) profundiza también en la historicidad arquitectónica del monasterio, reconociendo en este una construcción atípica, compuesta por la experimentación y el ensayo de varios elementos (como sus dos atrios y sus dos capillas abiertas) que rompen con los lineamientos de la arquitectura conventual del siglo XvI.

Desde otra perspectiva, Daniel Nemser (2017) proporciona una lectura atenta a la espacialidad del proyecto civilizatorio colonial, particularmente en Nueva España. El problema para Nemser es que no sería la raza el único elemento caracterizador de una construcción discursiva sobre la diferencia y la identidad (construcción social) sino las condiciones de espacialidad que favorecen la existencia de las categorías de casta y raza. Nemser nos permite introducir elementos atingentes a los procesos de concentración de personas y a la formación de lugares e identidades en el contexto de la llamada República Dual, operativa desde el siglo Xvi en el mundo colonial mesoamericano. Ciertamente, Tlaxcala no corresponde completamente al tipo de casos que Nemser utiliza para argumentar las condiciones de violencia y dominación como trasfondo de la movilización de personas en las concentraciones o Pueblos de Indios. Debido a su condición de aliados o colaboradores, el proyecto colonial en Tlaxcala mantiene fueros y condiciones territoriales específicas que integran el gobierno indio sobre la base de instituciones coloniales asentadas en la nueva ciudad (Martínez 2008: 135-195). Tlaxcala representa, en este sentido, un proyecto que siendo parte de la imposición colonial es también diferente en su diseño y ejecución.

En nuestro análisis mantenemos una perspectiva en la cual la ciudad de Tlaxcala funciona como ejemplo de la proyección de una civilidad indiana. Por ello nos parece prudente retomar la idea de civilidad (civitas) para comprender su particularidad dentro de la Nueva España. Volvemos a la obra de Lewis Hanke $(1959,1974)$, quien permite introducir el tipo de construcción discursiva 


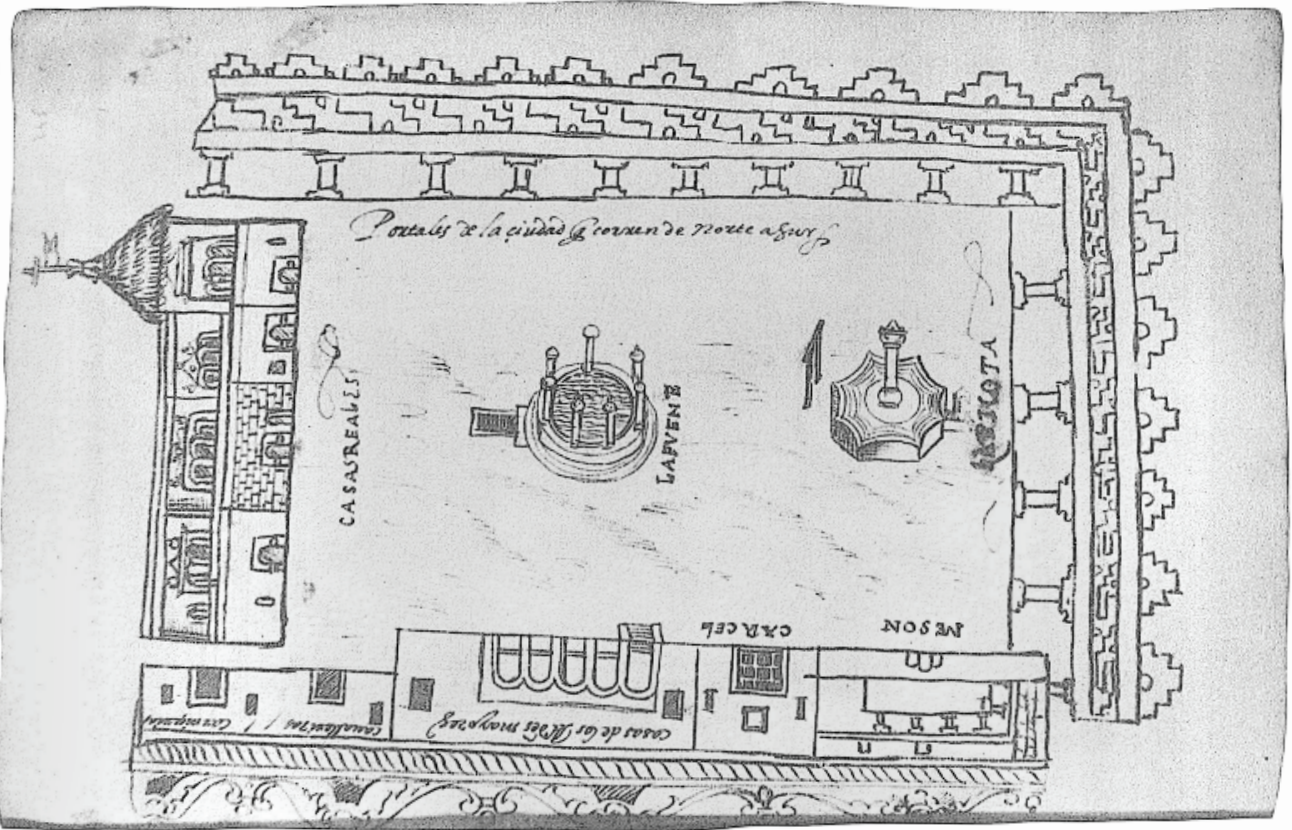

Figura 1. Casas de los al[cal]des mayores. Caballerizas. Carnicerías. Mesón. Cárcel. Casas reales. La fuente. La picota. Portales de la ciudad, que corren de norte a sur (Muñoz Camargo 1981 [1584]: cuadro 17). Figure 1. Houses of the chief colonial administrators. Stables. Butchers. Inn. Jail. Royal houses. Fountain. Pillory. City gates, running north to south (Muñoz Camargo 1981 [1584]: plate 17.

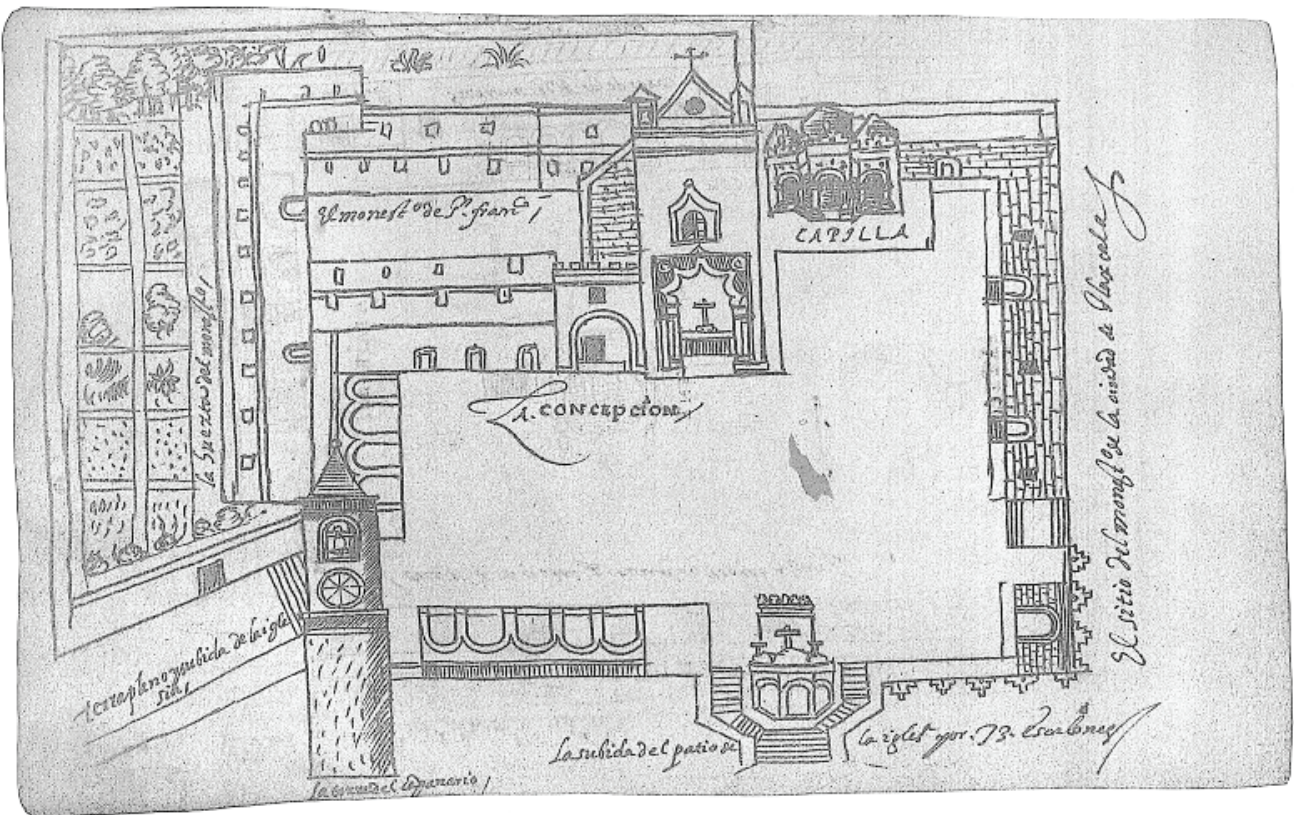

Figura 2. Terraplén y subida de Igles[i]a. La huerta del monast[eri]o. La torre del campanario. El monast[eri]o de S[a] n Fran[cis]co. La subida del patio de la igles[i]a por 73 escalones. La Concepción Capilla. El sitio del monast[eri]o de la ciudad de Tlaxcala (Muñoz Camargo 1981 [1584]: cuadro 18). Figure 2. Rampart and slope to the church. Monastery garden. Bell tower. San Francisco Monastery. Entry to the church courtyard via 73 steps. La Concepción Chapel. Plan of the monastery of the city of Tlaxcala (Muñoz Camargo 1981 [1584]: plate 18). 
realizada sobre el indio, especialmente relacionada con un análisis del trasfondo teórico-político aristotélico, es decir, una lectura de la alteridad basada en la idea de lo bárbaro como in-civilizado. Este asunto es central en su estudio sobre la disputa de Valladolid y la capacidad racional de los indios, cuestión que constituye luego una fuerte crítica sobre el prejuicio racial en el mundo moderno. Así también, conviene incorporar el trabajo de Anthony Pagden (1988), en el cual se profundiza la relación directa entre la configuración de una civilidad occidental y la oposición de lo bárbaro en términos aristotélico-tomistas (y su extensión hacia lo indio), a partir de la expansión europea del siglo xvi. Tampoco podemos omitir la idea de la "superioridad natural" de europeos, blancos, frente a otras razas o castas (africanos, indios y sus mestizajes), elementos centrales en la lectura sobre la construcción social realizada durante el período colonial en el Nuevo Mundo (Gerbi 1982, Restall 2003).

Sobre este asunto queremos enfatizar nuestra interpretación sobre la Descripción atendiendo a un modo de civilidad indiana presente tanto en el relato alfabético y en los dos textos visuales (figs. 1 y 2) como en la materialidad de la ciudad de indios, Tlaxcala. En rigor, esta civilidad indiana orienta un proyecto civilizatorio realizado en la ciudad y provincia de Tlaxcala, que está directamente relacionado con la interacción y apropiación de códigos culturales en una dimensión espacial-urbana y socio-política que, precisamente, como articulación de una civilidad nueva, nos permite avizorar en ella un modo civilizatorio alternativo. El gesto codigofágico acontece en el acomodo y adaptación de la espacialidad por parte del diseño (europeo), pero con la continuidad de un poder político indio. Entonces, la creación espacial-urbana de la ciudad de Tlaxcala se vuelve parte de un proyecto civilizatorio indiano dispuesto a negociar y adaptar sus códigos culturales y sus componentes socio-políticos.

\section{La Malinche y la matanza de Cholula}

La escena titulada por Muñoz Camargo "Templo de Quetzacóatl” (fig. 3) trata sobre la matanza de Cholula. ${ }^{5}$ En esta escena, la Malinche es fácilmente identificable. Si bien no es el único texto visual en donde se la presenta, nos permite aclarar el modo de representación e intervención que tiene en la compleja semiosis comunicativa entre nativos y europeos.
La escena es cruel. Se muestra el templo de Quetzalcóatl rodeado y atacado por tropas tlaxcaltecas e hispanas. Por parte de los cholultecas, la defensa es armada, asunto tendencioso pues otras versiones indican que la matanza se realiza sobre indios desarmados (Sahagún 1979 [1569]: 769-770). Cortés dirige el ataque y tras él (como en la mayoría de las escenas de la Descripción donde aparece) está la Malinche con su mano derecha en alto, entregando ayuda en el campo de batalla. Es posible ver un prisionero en el centro superior de la escena, junto a él dos tlaxcaltecas dialogando y señalándolo. El texto visual pone en escena un momento que determina las acciones militares de los tlaxcaltecas en apoyo a Cortés en la conquista de México. La escena adecua los hechos para entregarles un lugar en el relato que Muñoz Camargo quiere consolidar y en el cual la traición que tenían urdida los cholultecas fundamenta el violento desenlace.

Federico Navarrete (2007a) analiza esta escena teniendo como referencia la traducción y apropiación cultural de la figura de Santiago Mataindios en Nueva España, que se presenta por primera vez en esta escena y luego en buena parte de la narrativa de la Descripción (y del Lienzo). ${ }^{6}$ Navarrete posiciona la negociación como trasfondo para la construcción de una iconografía intercultural que cruza los horizontes europeos y mesoamericanos de manera correlacionada y donde se releva la yuxtaposición de imaginarios y repertorios iconográficos junto con la función político-religiosa que tuvo Santiago Mataindios en el Nuevo Mundo, tanto para el orden colonial como para los propios indios (tlaxcaltecas).

No obstante, es preciso profundizar en el contenido del texto visual considerando el lugar de la Malinche. Para ello es importante destacar dos perspectivas específicas sobre su figura. Destacamos primero -desde un enfoque filosófico- la propuesta de Bolívar Echeverría:

Puede pensarse, sin embargo, que la Malintzin de 1519-1520, la más interesante de todas las que ella fue en su larga vida, prefigura una realidad de mestizaje cultural un tanto diferente, que consistiría en un comportamiento activo -como el de los hablantes del latín vulgar, colonizador, y los de las lenguas nativas, colonizadas en la formación y el desarrollo de las lenguas romances- destinado a trascender tanto la forma cultural propia como la forma cultural ajena, para que ambas, negadas de esta manera, puedan afirmarse en una forma tercera, diferente de las dos (Echeverría 2005: 25). 


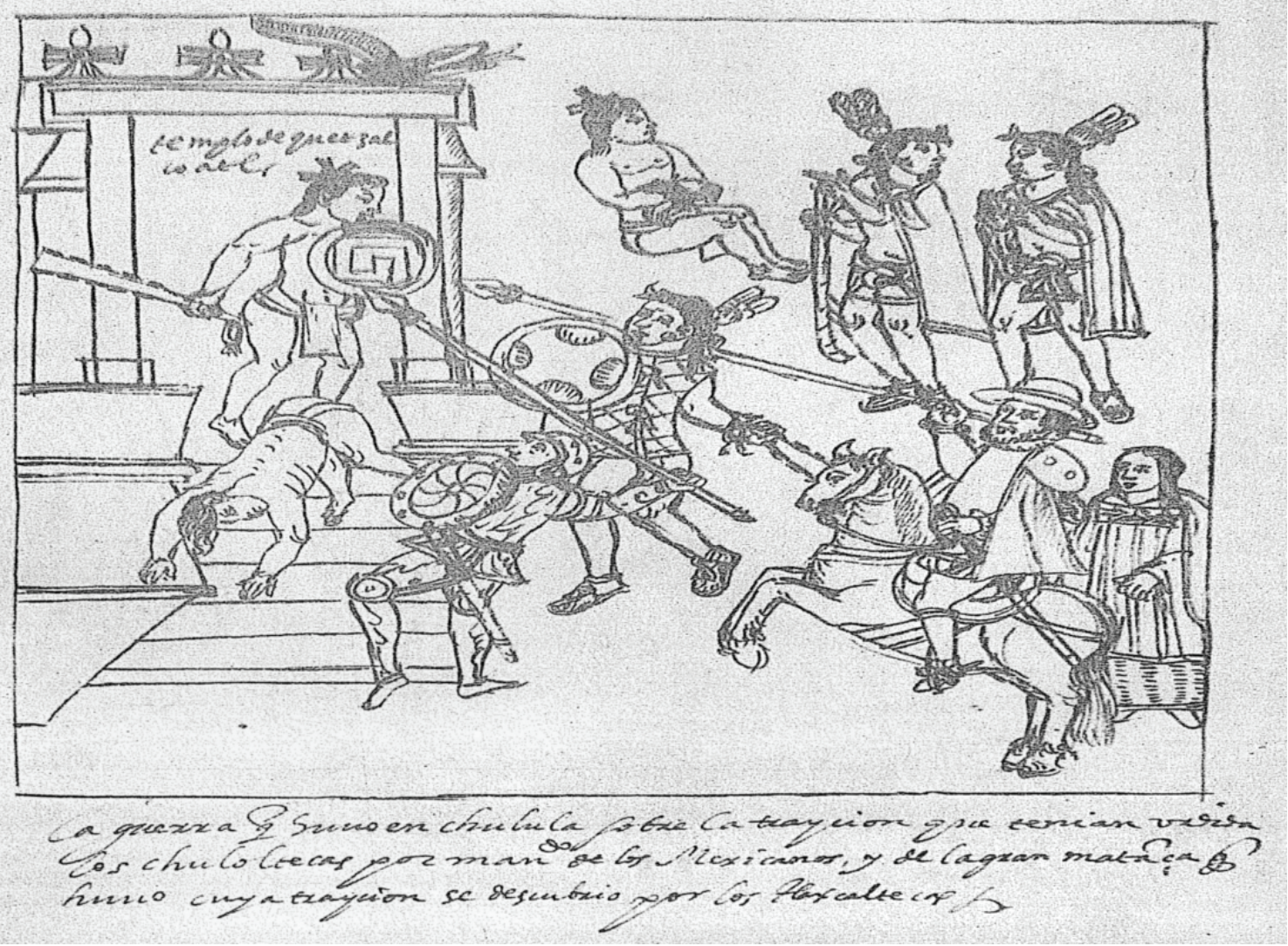

Figura 3. Templo de Quetzalcóatl. La guerra que hubo en Cholula sobre la traición que tenían urdida los chuloltecas por man[da]do de los mexicanos, y de la gran matanza que hubo, cuya traición se descubrió por los tlaxcaltecas (Muñoz Camargo 1981 [1584]: cuadro 36). Figure 3. Temple of Quetzalcoatl. The war that occurred in Cholula resulting from the betrayal plotted by the Chuloltecas at the urging of the Mexicanos, and the massacre that resulted when the Tlaxcaltecas discovered the treachery (Muñoz Camargo 1981 [1584]: plate 36).

La Malintzin (el mestizaje cultural), cuestiona desde la perspectiva de Echeverría la concepción binaria proponiendo una tercera forma. Este detalle nos permite reflexionar sobre una noción de mestizaje que no carga con las necesidades de fundamentación en elementos culturales esenciales. La idea de una forma tercera es precisamente la clave para comprender el grado de creatividad presente en la figura de la Malinztin.

Por su parte, Federico Navarrete (2007a) problematiza desde un enfoque historiográfico las relaciones discursivas entre la Malinche, el simbolismo de la Virgen María y el cerro rebautizado como La Malinche en Tlaxcala. Navarrete destaca cómo, en los textos visuales del Lienzo y de la Descripción, la continuidad del relato conduce a una construcción identitaria que reivindica, a través de la imagen de la Malinche, elementos culturales de intercambio, desencubriendo las relaciones de interdependencia y negociación que operan entre los horizontes culturales hispanos y tlaxcaltecas.

En nuestro acercamiento remarcamos la relación entre la Malinche y su funcionalidad simbólico-identaria. Por un lado, consideramos su activa participación en la composición de una tercera opción o tercera forma que redirecciona la noción de mestizaje cultural (Echeverría 2005); por otro, realzamos el contenido histórico en el simbolismo de la Malinche y con ello sus posibilidades de vectorización en el intercambio de horizontes culturales hispanos y tlaxcaltecas (Navarrete 2007a, 2012). Ambos puntos de vista permiten rastrear en la figura de la Malinche el traspaso de elementos simbólicoidentitarios en construcción e intercambio. Entonces, es posible comprender el ejercicio codigofágico de la Malinche como una bisagra o enlace entre los horizontes culturales y, precisamente, en cuanto bisagra como un 
movimiento creativo en la negociación (en el devorarse) entre códigos culturales. En suma, la codigofagia presenta en la figura de la Malinche una vectorización de la semiosis comunicativa entre nativos y europeos, basada en los efectos formativos o propositivos del encuentro entre elementos simbólico-identitarios y en la negociación conflictiva entre horizontes culturales.

\section{Los conquistadores tlaxcaltecas}

Sin duda, buena parte de los textos visuales de la Descripción corresponden a escenas bélicas relacionadas con las guerras de conquista en Mesoamérica. Podemos dedicar un breve análisis a esta serie de textos visuales focalizando nuestro esfuerzo en cinco de ellos. El primero (fig. 4) es el relato de la batalla de México-Tenochtitlán, donde es evidente la entrada de las tropas tlaxcaltecas por las calles y su enfrentamiento con los mexicas. Podemos ver también en la retaguardia a un español a caballo apoyando el avance tlaxcalteca. El segundo (fig. 5) responde a las guerras de conquista en Nueva Galicia. El tercero (fig. 6) remite a la conquista de California. El cuarto (fig. 7) a la conquista de Guatemala. Y el quinto (fig. 8) a las guerras en Oaxaca. Las escenas son muy similares entre sí, claramente responden a un modelo que se reitera y adapta. Si observamos algunos patrones en estos textos visuales, ciertamente distinguimos que en cada uno españoles y tlaxcaltecas comparten el lado izquierdo de la escena. Decoradas con tocados y plumas, las tropas tlaxcaltecas son visiblemente identificables con sus estandartes acompañando a la caballería española, la cual reitera la apropiación de la iconografía de Santiago Mataindios. En el lado derecho de la escena se observa a los otros indios, bárbaros y gentiles, en notoria actitud de resistencia bélica. Asimismo, en el extremo superior derecho de cada figura hay una referencia al topónimo específico a través de glifos nahuas.

Es canónico que el objetivo de estas escenas sea la aclaración y el posicionamiento de los tlaxcaltecas como colaboradores directos en las campañas de conquista (Mignolo 1987, Velasco 2003, Navarrete 2007a, Martínez 2008, Añón 2012). La historicidad de Tlaxcala remite a estos eventos de diferentes maneras. Destacamos la perspectiva de Mónica Domínguez (2013), que posiciona, específicamente para el caso de Tlaxcala en el Lienzo y en la Descripción, un acercamiento al ethos militar y a la cultura visual, destacando el uso de códigos culturales y visuales, tanto europeos como mesoamericanos, en la creación de imágenes que completaran sus particulares necesidades de representación político-simbólica dentro del orden colonial. Esta perspectiva permite reconocer el lugar de lo militar en la construcción identitaria colonial, en europeos e indios, de la primera modernidad. Como tal, esta identidad militar "debe ser analizada dentro de los procesos de acomodación y transculturación" (Domínguez 2013: 226) provocados por la conquista y colonización hispana.

Por otra parte, Matthew Restall y Florine Asselbergs (2007) proponen un valioso acercamiento a las fuentes españolas, nahuas y mayas de la conquista de Guatemala. Ahí la perspectiva nahua es analizada considerando la evidencia pictórica (principalmente Lienzo de Tlaxcala) y los testimonios escritos por veteranos tlaxcaltecas, invasores aliados a los españoles. Asimismo, Pedro Escalante (2001) aporta un análisis historiográfico focalizado en la participación tlaxcalteca en la conquista y colonización de Centroamérica (específicamente Guatemala, El Salvador, Honduras y Nicaragua). Destacamos su referencia a las imágenes de la Descripción como enlaces con las narraciones de los españoles y con documentos y testimonios coloniales de carácter jurídico. En este punto, se aprecia el trabajo de José Rivera Villanueva (2010), quien ha compilado y paleografiado documentos relacionados con el proyecto hispano de colonización del norte de Nueva España y, específicamente, sobre la movilización de tlaxcaltecas en la diáspora de 1591. Detalles específicos sobre las condiciones para la colonización son bien expuestos por Rivera, como los repartimientos de tierra, las exenciones de servicios y las licencias para montar a caballo, entre otros. Rivera Villanueva (1999) remarca el contexto de la pacificación de la Gran Chichimeca y su efecto directo en la diseminación de la herencia cultural nahua transmitida por los colonizadores tlaxcaltecas a los pobladores fronterizos.

En suma, en estos textos visuales hay por lo menos dos intenciones interrelacionadas. Por una parte, la evidente y leal participación de los tlaxcaltecas en la conquista y colonización de diversas latitudes, y por otra, la búsqueda de validación de sus acciones y méritos frente al orden colonial. Finalmente, esta selección de textos visuales busca cimentar un ejercicio hermenéutico atento a la continuidad de un relato que redirecciona un sentido político-militar como trasfondo de una construcción codigofágica, esto es, los tlaxcaltecas como conquistadores y civilizadores. 


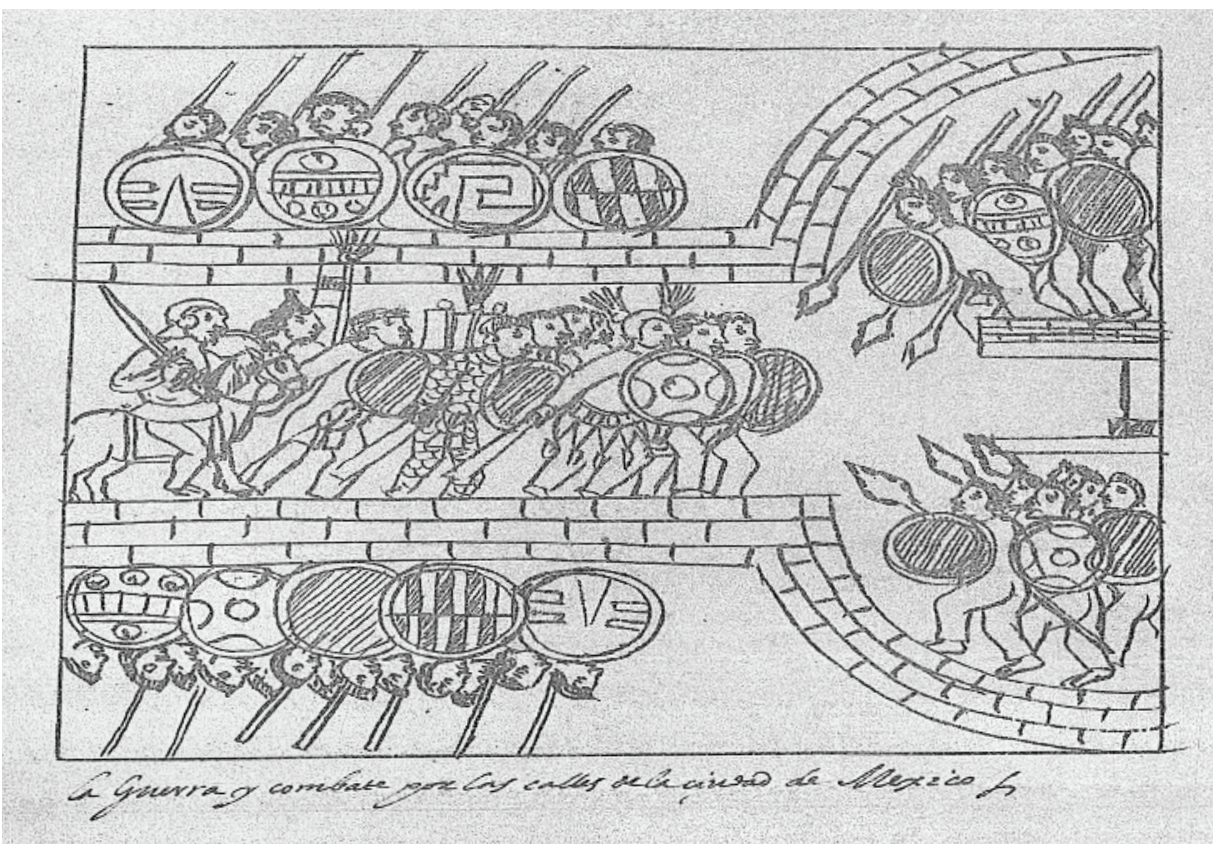

Figura 4. Yc quinhualtocaque caltzallan. [así los siguieron entre las casas]. La guerra y combate por las calles de la ciudad de México (Muñoz Camargo 1981 [1584]: cuadro 73). Figure 4. Yc quinhualtocaque caltzallan. [asílos siguieron entre las casas]. The war and fighting in the streets of Mexico City (Muñoz Camargo 1981 [1584]: plate 73).

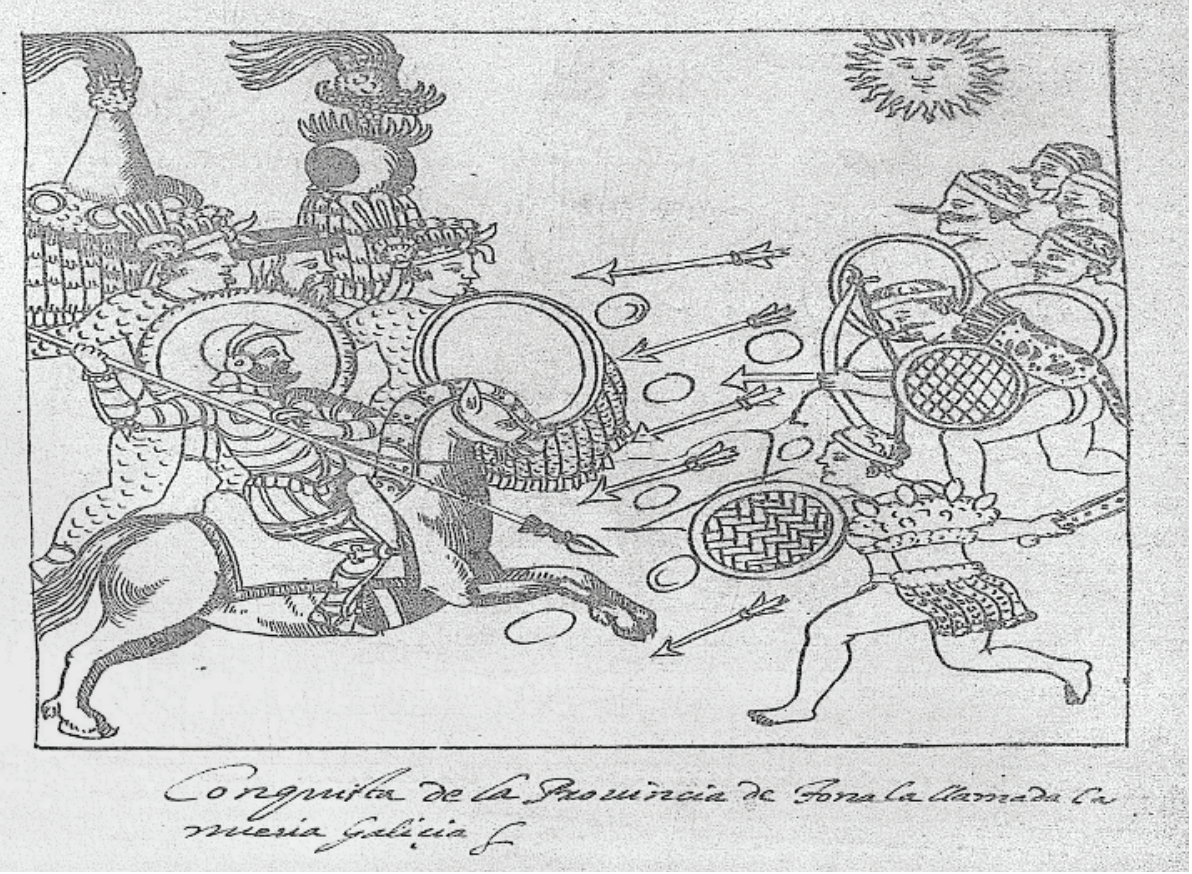

Figura 5. Tonalan. Conquista de la provincia de Tonala, llamada la Nueva Galicia (Muñoz Camargo 1981 [1584]: cuadro 82). Figure 5. Tonalan. Conquest of the province of Tonala, called Nueva Galicia (Muñoz Camargo 1981 [1584]: plate 82). 


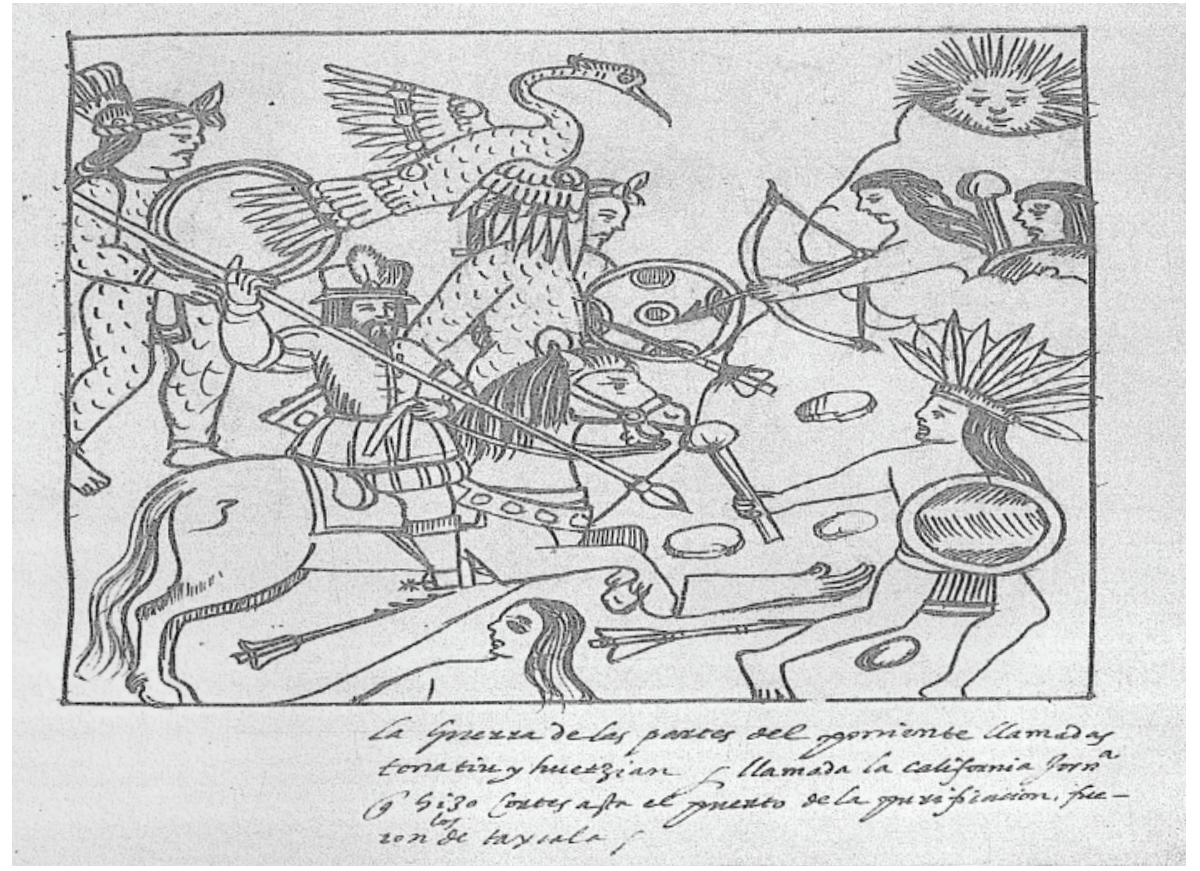

Figura 6. La guerra de las partes del poniente llamadas Tonatin y Huetzian y llamada la California forma que hizo Cortés [h] asta el puesto de la pacificación, fueron los de T[1]axcala (Muñoz Camargo 1981 [1584]: cuadro 100). Figure 6. The war of the western cities called Tonantin and huetzian and California, wich Cortés engaged in until their pacification, wew of Tlaxcala (translated from the spanich) (Muñoz Camargo 1981 [1584]: plate 100).

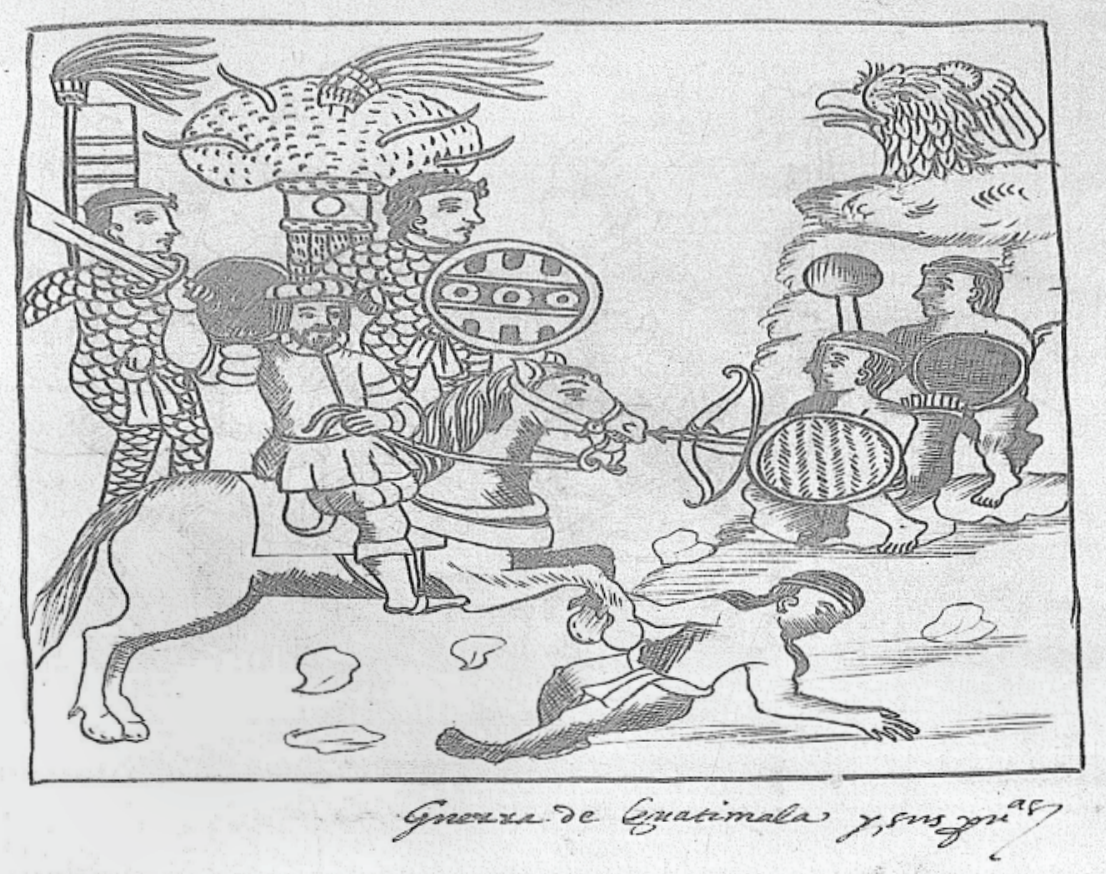

Figura 7. Guerra de Guatemala y sus provincias (Muñoz Camargo 1981 [1584]: cuadro 106). Figure 7. War of Guatemala and its provinces (Muñoz Camargo 1981 [1584]: plate 106). 


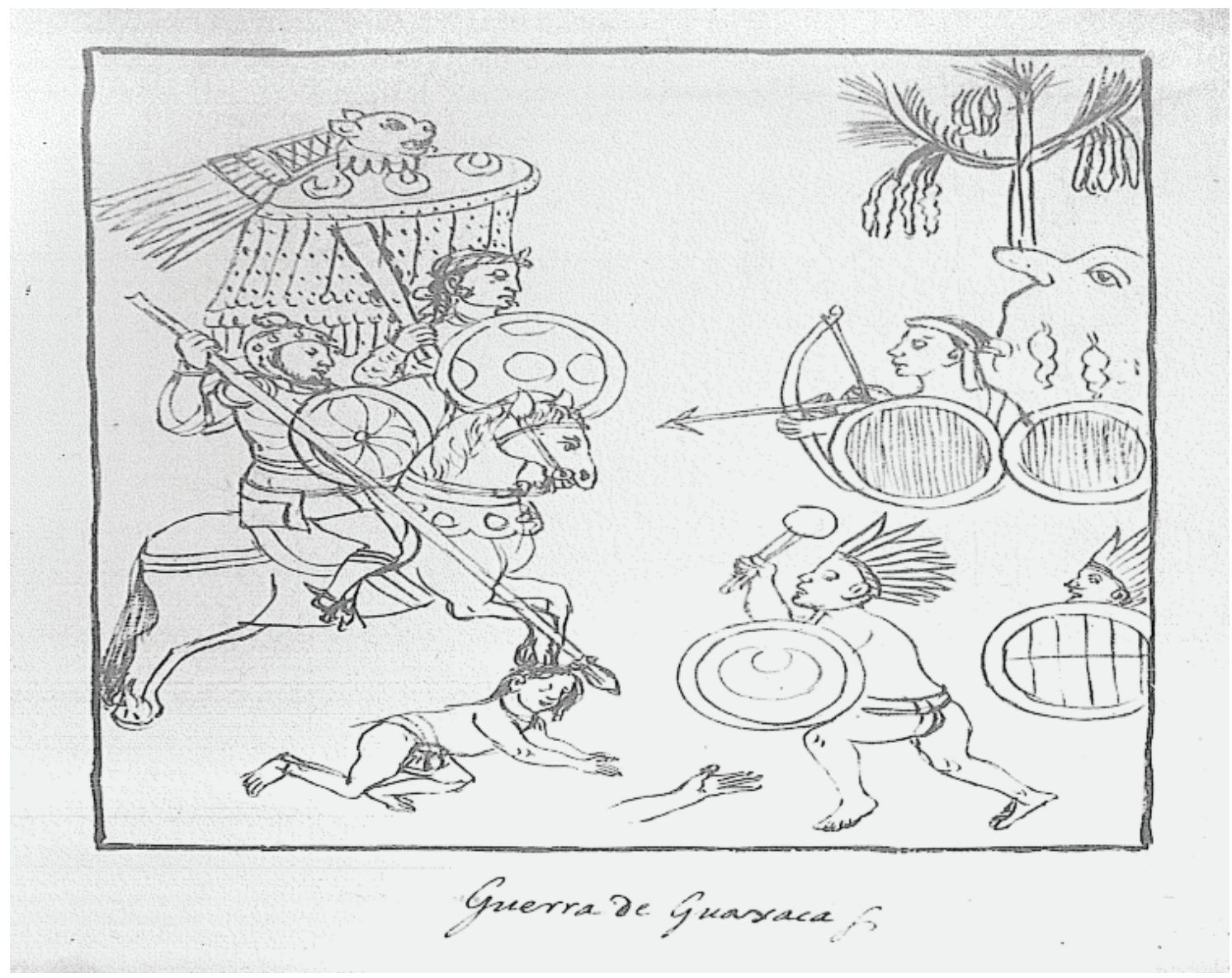

Figura 8. Guerra de Guaxaca (Muñoz Camargo 1981 [1584]: cuadro 149). Figure 8. War of Guaxaca (Muñoz Camargo 1981 [1584]: plate 149).

\section{CONSIDERACIONES FINALES}

Las crónicas de indios coloniales permiten una proyección en la cual se rememora y reconstruye una experiencia histórica específica. Es menester, por lo tanto, ubicar este asunto desde una perspectiva abierta a pensar los conceptos y delinear otras lecturas que posibiliten reconocer sus motivaciones, expectativas y vectorizaciones. En las crónicas de indios coloniales se entrelaza la recomposición de una subjetividad alternativa, esto es, el indio, desde la positividad discursiva de los elementos identitarios sobrevivientes y resemantizados en el encuentro-choque con el proyecto civilizatorio moderno-occidental. Queremos destacar cómo esta escritura alude al tema de forma directa, asumiendo el intercambio y la transferencia de códigos culturales -junto con sus asimetrías- como elemento central. A través del relato de la Descripción es posible comprender su operatividad y es plausible evidenciar también el proyecto civilizatorio que se cataliza en Tlaxcala. En la Descripción se re-construyen no solo los acontecimientos de la conquista de México, sino también se re-articula la posición de enunciación de los propios tlaxcaltecas. Recordemos que el título de la Descripción finaliza aludiendo a la ciudad y provincia de Tlaxcala con la decidora frase "para el buen gobierno y ennoblecimiento dellas". Se logra aquí una plataforma para reflexionar sobre los alcances de una propuesta específica en torno al fundamento filosófico-político presente en la obra. En ella, Muñoz Camargo tiene en consideración la imbricación y la propositividad de un posicionamiento enunciativo que no se resta de ser parte activa de un proyecto mayor, por cierto, civilizatorio, que acontece en el "lugar de la tortilla", Tlaxcallan. 
En el horizonte de la codigofagia (Echeverría 2001, 2005), podemos afirmar que en la Descripción es posible avizorar y apuntalar la noción de civilidad alternativa como lectura sobre la creación y la trayectoria de un proyecto político y civilizatorio en y desde el Nuevo Mundo. En consecuencia, Muñoz Camargo es la voz de una civilidad alternativa, de un proyecto civilizatorio que atiende al intercambio de códigos culturales desde la explicitación de los mismos. Cuando desciframos su obra bajo la consideración de su propuesta civilizatoria es posible observar cómo aquellos elementos indianos se relocalizan en medio de la imposición colonial, y cómo la imposición colonial es, a su vez, capaz de adaptarlos e incluso reconocerlos.

Hablamos entonces de la canalización de un discurso sobre un lugar, Tlaxcala, que logra establecer dentro del entramado colonial, en su realidad política y en textos como los de Muñoz Camargo, una propuesta civilizatoria que sostiene una historicidad construida sobre la base de una conflictiva negociación entre lo prehispánico y lo colonial, en un contexto de supervivencia frente a un cambio radical en el mundo cultural nahua. Tlaxcala y Diego Muñoz Camargo traducen y componen un mismo discurso en este respecto, ambos construyen y reconstruyen, traspasan y transfieren, en dimensiones disímiles pero interrelacionadas, un relato de colaboración y convivencia interétnica. Finalmente, la jugada de Muñoz Camargo es ofensiva, propositiva, en el horizonte de un mundus novus en movimiento, donde hay lugar para un modo alternativo, un modo indio, tlaxcalteca, en el desarrollo de la colonización (y la civilización) novohispana.

\section{NOTAS}

${ }^{1}$ Respecto de la noción de "texto visual", queremos retomar la tensión entre la imagen y el texto. Asunto trabajado desde la perspectiva de la teoría de la imagen, es quizá Mitchell (2009) quien mejor sintetiza este problema en el concepto de "imagen-texto". En nuestro acercamiento buscamos relevar la equivalencia y correlación entre el texto alfabético y el texto visual (imagen). Sobre ello, comprendemos que un texto funciona en cualquier unidad de comunicación; es siempre multisemiótico o multimodal; se relaciona con prácticas discursivas estando inserto en redes textuales o contextos que mantienen elementos verbales y/o no verbales. Entonces, el texto -textum- es un "tejido", una "textura", una "contextura" (Vox 2002: 508) que no funciona aisladamente sino en relación con otros. Este elemento relacional o intertextual "en sentido amplio", incluso polifónico (Bajtin 1986), constituye al texto como catalizador de prácticas semióticas a la vez que de procesos generadores o reproductores de prácticas socio-discursivas. Covarrubias (2006 [1611]: 960) indica que la palabra testo significa la "lectura de un autor", una experiencia del lector como proceso interpretativo que considera elementos contextuales (socioculturales). Entonces, la noción de "texto visual" retoma al texto en modo expansivo donde lo visual acontece como "visión socializada" y la relación sujeto-objeto está mediada por redes significantes que le otorgan sentido (Walker \& Chaplin 2002: 41-42).

${ }^{2}$ Se trata de experiencias polisensuales o "multisensoriales": textiles, cantos, bailes, comidas, entre muchos otros. Son sistemas de registro y comunicación de carácter performativo que no se reducen a la diástasis oralidad-escritura. Las experiencias polisensuales conducen reconstrucciones semánticas del pasado en el presente (memoria social) desde un horizonte de traspaso y tensión intercultural (Abercrombie 1998: 413).

${ }^{3}$ Existe una edición facsimilar de 1981 y otras dos versiones paleográficas realizadas en 1984 y 2000. Como hemos señalado utilizaremos la edición facsimilar para el análisis de los textos visuales. Esta edición no estuvo exenta de polémica. Hubo una acusación de "piratería académica", por parte de Hanns J. Prem (1985) sobre el trabajo de Acuña, publicada en una reseña sobre su edición facsimilar. Esto condujo a una fuerte defensa del trabajo realizado por Acuña (1986) donde queda en evidencia la relevante y sincera labor científica desarrollada en la edición y divulgación de la Descripción.

${ }^{4}$ Producido circa 1552 el Lienzo de Tlaxcala es portador de la percepción tlaxcalteca de la conquista de México. Entre las ediciones del Lienzo podemos destacar el trabajo de Alfredo Chavero (1979), quien reproduce en una versión analítica las escenas. El Lienzo constituye uno de muchos materiales o textos visuales producidos con anterioridad y durante el proceso de colonización novohispana. La correlación entre las imágenes del Lienzo y la Descripción ha sido trabajada por Andrea Martínez (1990) a partir del análisis de los contextos de producción de ambos. Ahí sostiene: "una obra colectiva encargada por el cabildo indio de Tlaxcala a uno o varios dibujantes, tanto en su versión mural como en su versión transportable" (Martínez 1990: 153). Destacamos también a Manuel Núñez Rodríguez (2012), quien releva la forma específica y alternativa de "escribir la historia" que se encuentra en el Lienzo. Núñez Rodríguez entiende el desarrollo de las imágenes del Lienzo desde una "dimensión mestiza", es decir, desde la fusión entre la tradición indígena y la hispana. Respecto del lugar de la imagen en el mundo mesoamericano es posible considerar el trabajo de Serge Gruzinski (2004, 2006). Así también, respecto del contenido de los códices mesoamericanos y de la continuidad de escritura pictográfica pre- $\mathrm{y}$ postconquista destacamos el trabajo de Pablo Escalante (2010). 


\begin{abstract}
${ }^{5}$ Conviene recordar que la matanza de Cholula (18 de octubre de 1519) es uno de los acontecimientos principales en la conquista de México. Cholula era un centro político importante que rivalizaba con Tlaxcala. La matanza consistió en el asesinato de la élite indígena en medio de una celebración religiosa en la gran pirámide y las calles de Cholula. En la Historia de Tlaxcala indica: "Entrados pues por la provincia de Cholula, en muy breve tiempo fue destruida por muy grandes ocasiones que para ello dieron y causaron los naturales de aquella ciudad, la cual destruida y muerta en esta entrada gran muchedumbre de chol[ul]tecas, corrió la fama por toda la tierra hasta México, donde puso horrible espanto, y más en ver y entender que los tlaxcaltecas se habían confederado con los dioses, que así generalmente eran llamados los nuestros en toda la tierra de este Nuevo Mundo, sin podelles dar otro nombre" (Muñoz Camargo 2000 [1584]: 188). Aquí se posiciona claramente la justificación de sus acciones durante la matanza de Cholula.

${ }^{6}$ Con respecto a Santiago Mataindios relevamos la lectura de Javier Domínguez (2008) que analiza las continuidades iconográficas con el mundo medieval europeo, específicamente en la españolización de Jacobo con la figura de Santiago y luego su impacto en la conquista y colonización de Nueva España y el Perú.
\end{abstract}

\section{REFERENCIAS}

Abercrombie, T. 1998. Pathways of memory and power. Madison: University of Wisconsin Press.

AcuñA, R. 1981. Estudio preliminar. En Descripción de la ciudad y provincia de Tlaxcala de las Indias y del Mar Océano para el buen gobierno y ennoblecimiento dellas, D. Muñoz Camargo, pp. 8-49. México DF: Universidad Nacional Autónoma de México.

Acuña, R. 1986. Descripción de la ciudad y provincia de Tlaxcala. Una respuesta a Hanns Prem. México DF: Universidad Nacional Autónoma de México.

Adorno, R. 1992. El indio ladino en el Perú colonial. En De palabra y obra en el Nuevo Mundo. Imágenes interétnicas, M. Gutiérrez Estévez et al., Eds., pp. 369-375. Madrid: Siglo XXI.

AÑón, V. 2012. La palabra despierta. Tramas de la identidad y usos del pasado en crónicas de la conquista de México. Buenos Aires: Corregidor.

BaCHMANN-Medick, D. 2016. Cultural turns: new orientations in the study of culture. Berlín-Boston: De Gruyter.

Bajtin, M. 1986. Problemas de la poética de Dostoievski. México DF: Fondo de Cultura Económica.

Bernand, C. 2001. Mestizos, mulatos y ladinos en Hispanoamérica: un enfoque antropológico de un proceso histórico. En Motivos de la antropología americanista. Indagaciones en la diferencia, M. León-Portilla, Coord., pp. 105-131. México DF: Fondo de Cultura Económica.
Chavero, A. 1979. El lienzo de Tlaxcala. México DF: Universidad Nacional Autónoma de México.

Cornejo Polar, A. 2011. Escribir en el aire. Ensayo sobre la heterogeneidad socio-cultural en las literaturas andinas. Lima: Latinoamericana.

Cortés, R. \& Zamora, M. 2016. Narradores indígenas y mestizos de la época colonial (siglos XVI y XVII). Zona andina $y$ mesoamericana. Lima: Latinoamericana.

Covarrubias, S. 2006 [1611]. Tesoro de la lengua española. Madrid-Frankfurt: Iberoamericana-Vervuert.

Daneri, J. 2016. Diego Muñoz Camargo (1529-1599). En Narradores indígenas y mestizos de la época colonial (siglos XVI $y$ XVII). Zona andina y mesoamericana, R. Cortés \& M. Zamora, Eds., pp. 61-84. Lima: Latinoamericana.

DomíngueZ, J. 2008. De apóstol matamoros a yllapa mataindios: dogmas e ideologías medievales en el (des)cubrimiento de América. Salamanca: Universidad de Salamanca.

Domínguez, M. 2013. Military ethos and visual culture in post-conquest Mexico. Dorchester: Dorset Press.

Echeverría, B. 2001. La identidad evanescente. En Las ilusiones de la modernidad, B. Echeverría, Ed., pp. 57-77. Quito: Tramasocial.

Echeverría, B. 2005. La modernidad de lo barroco. México DF: Era.

ECheverríA, B. 2010. Meditaciones sobre el barroquismo. En Modernidad y blanquitud, B. Echeverría, Ed., pp. 183-207. México DF: Era.

Escalante, P. 2001. Los tlaxcaltecas en Centro América. San Salvador: Consejo Nacional para la Cultura y el Arte.

Escalante, P. 2010. Los códices mesoamericanos antes y después de la conquista española. México DF: Fondo de Cultura Económica.

FARRISS, N. 1985. Recordando el futuro, anticipando el pasado. Tiempo histórico y tiempo cósmico entre los mayas de Yucatán. En La memoria y el olvido. Segundo simposio de historia de las mentalidades, pp. 47-60. México DF: Instituto Nacional de Antropología e Historia.

GARIBAY, Á. 2007. Historia de la literatura náhuatl. México DF: Porrúa.

Gerbi, A. 1982. La disputa del nuevo mundo. Historia de una polémica, 1750-1900. México DF: Fondo de Cultura Económica.

Gibson, C. 1950. The identity of Diego Muñoz Camargo. The Hispanic American Historical Review 30: 195-208. Durham.

GRUZINSKI, S. 2004. La colonización de lo imaginario. Sociedades indígenas y occidentalización en el México español. Siglos XVI-XVIII. México DF: Fondo de Cultura Económica.

Gruzinski, S. 2006. La guerra de las imágenes. De Cristóbal Colón a "Blade Runner" (1492-2019). México DF: Fondo de Cultura Económica.

Gutiérrez, C. 1990. La arquitectura civil de la ciudad de Tlaxcala en el siglo xvi. (Notas sobre un dibujo de Muñoz Camargo). Anales del Instituto de Investigaciones Estéticas 61: 85-97. México DF. 
Gutiérrez, C. 1997. El convento de Nuestra Señora de la Asunción de Tlaxcala en el siglo xvi. Notas sobre un dibujo de Diego Muñoz Camargo. Anales del Instituto de Investigaciones Estéticas 71: 5-36. México DF.

Hanke, L. 1959. Aristotle and the american indians. A study in race prejudice in the modern world. Chicago: Henry Regnery Company.

Hanke, L. 1974. All mankind is one. A study of the disputation between Bartolomé de Las Casas and Juan Ginés de Sepúlveda on the religious and intellectual capacity of the american indians. DeKab: Northern Illinois University Press.

Hernández, R. 2011. Diego Muñoz Camargo. En Historiografía mexicana. Historiografía novohispana de tradición indígena, J. Romero, Coord., pp. 201-311. México DF: Universidad Nacional Autónoma de México.

León Portilla, M. 1964. El reverso de la conquista. Relaciones aztecas, mayas e incas. México DF: Editorial Joaquín Mortiz.

Lienhard, M. 1983. La crónica mestiza en México y el Perú hasta 1620: Apuntes para su estudio histórico-literario. Revista de Crítica Literaria Latinoamericana 17: 105-115. Pittsburg.

López Austin, A. 2014. Hombre-Dios. Religión y política en el mundo náhuatl. México DF: Universidad Nacional Autónoma de México.

Martínez, A. 1990. Las pinturas del Manuscrito de Glasgow y el Lienzo de Tlaxcala. Revista de Cultura Náhuatl 20: 141-162. México DF.

Martínez, A. 2008. Un gobierno de indios: Tlaxcala 1519-1750. México DF: Fondo de Cultura Económica.

Mignolo, W. 1987. El mandato y la ofrenda: La Descripción de la Ciudad y Provincia de Tlaxcala, de Diego Muñoz Camargo, y las Relaciones de Indias. Nueva Revista de Filología Hispánica 35 (2): 451-484. México DF.

Mitchell, W. 2009. Teoría de la imagen. Ensayos sobre representación verbal y visual. Madrid: Akal.

Muñoz Camargo, D. 1981 [1584]. Descripción de la ciudad y provincia de Tlaxcala de las Indias y del Mar Océano para el buen gobierno y ennoblecimiento dellas. México DF: Universidad Nacional Autónoma de México.

Muñoz Camargo, D. 2000 [1584]. Descripción de la ciudad y provincia de Tlaxcala de las Indias y del Mar Océano para el buen gobierno y ennoblecimiento dellas. San Luis Potosí: El Colegio de San Luis-Gobierno del Estado de Tlaxcala.

Muñoz Camargo, D. 2013 [1590]. Historia de Tlaxcala. México DF: Universidad Autónoma de Tlaxcala-Centro de Investigaciones y Estudios Superiores en Antropología Social.

NAVARrete, F. 2007a. La Malinche, la Virgen y la montaña: el juego de la identidad en los códices tlaxcaltecas. História 26 (2): 288-310. Sao Paulo.

Navarrete, F. 2007b. Chimalpain y Alva Ixtlilxóchitl, dos estrategias de traducción cultural. En Indios, mestizos y españoles. Interculturalidad e historiografía en la Nueva España, D. Levín \& F. Navarrete, Coords., pp. 97-112. México DF: Universidad Autónoma de México.
Navarrete, F. 2008. Beheading and massacres. Andean and Mesoamerican representations of the Spanish Conquest. RES: Anthropology and Aesthetics 53/54: 59-78. Cambrigde.

Nemser, D. 2017. Infrastuctures of race. Concentration and biopolitics in colonial Mexico. Austin: The University of Texas Press.

NúÑEz Rodríguez, M. 2012. El lienzo de Tlaxcala. ¿Otra forma de escribir la historia? Semata, Ciencias Sociales y Humanidades 24: 55-72. Santiago de Compostela.

O'Phelan, S. \& Salazar, C. 2005. Passeurs, mediadores culturales y agentes de la primera globalización en el mundo ibérico, siglos XVI-XIX. Lima: Instituto Francés de Estudios Andinos.

Ortega, A. 2011. ¿Qué pregunta la filosofía desde América? En Filosofía desde América. Temas, balances y perspectivas, A. Ramírez, Coord., pp. 17-43. Quito: Abya Yala.

PAgden, A. 1988. La caída del hombre natural: el indio americano $y$ los orígenes de la etnología comparativa. Madrid: Alianza.

PAYÀs, G. 2010. El revés del tapiz. Traducción y discurso de identidad en la Nueva España (1521-1821). MadridFrankfurt: Iberoamericana-Vervuert.

Pratt, M. 1991. Arts of the contact zone. Profession 91: 3340. Nueva York.

Prem, H. 1985. Descripción de la ciudad y provincia de Tlaxcala de las Indias del Mar Océano para el buen gobierno y ennoblecimiento dellas by Diego Muñoz Camargo, René Acuña. Zeitschrift für Ethnologie 110 (2): 315-316. Berlín.

Rama, Á. 2004. La ciudad letrada. Santiago: Tajamar.

RAMOS, G. \& YANNAKAKIS, Y. 2014. Indigenous intellectuals: knowledge, power, and colonial culture in Mexico and the Andes. Durham: Duke University Press.

Restall, M. 2003. Seven myths of the spanish conquest. Nueva York: Oxford University Press.

Restall, M. \& Asselbergs, F. 2007. Invading Guatemala. Spanish, nahua, and maya accounts of the conquest wars. University Park: The Pennsylvania State University Press.

Revueltas, J. 2016. Dios en la tierra. México DF: Era.

Richter, A. 2015. Geschichte und Translation im kolonialen Mexiko. Eine Untersuchung ausgewählter historischer Schriften von Fernando de Alva Ixtlilxóchitl, Diego Muñoz Camargo und Hernando Alvarado Tezozomoc. HildesheimZürich-New York: Georg Olms Verlag.

Rivera, J. 1999. Los tlaxcaltecas: pobladores de San Luis Potosí. San Luis Potosí: Colegio de San Luis-Ocelote.

Rivera, J. 2010. Documentos inéditos para el estudio de los tlaxcaltecas en San Luis Potosí, siglos XVI-XVIII. Volumen III. Tlaxcala: Gobierno del Estado de Tlaxcala-Colegio de Historia de Tlaxcala-Proyecto editorial MKA.

Romero, J. 2011. Historiografía mexicana. Historiografía novohispana de tradición indígena. México DF: Universidad Nacional Autónoma de México.

Sahagún, B. 1979 [1569]. Historia general de las cosas de Nueva España. México DF: Porrúa.

STOLL, E. 2010. Competencia escrita, pragmática textual y 
tradiciones discursivas en la historiografía colonial (en los siglos XVI y XVII). En La renovación de la palabra en el bicentenario de la Argentina. Los colores de la mirada lingüistica, V. Castel \& L. Cubo de Severino, Eds., pp. 1273-1284. Mendoza: Editorial Facultad de Filosofía y Letras Universidad Nacional de Cuyo.

VALDEón, R. 2014. Translation and the spanish empire in the Americas. Amsterdam-Philadephia: John Benjamins Publishing Company.
Velasco, S. 2003. El 'coloquio de Tlaxcala' de Diego Muñoz Camargo. Estudios de Cultura Náhuatl 34: 307-329. México DF.

Vox. 2002. Diccionario Latín-Español. Barcelona: Bibliograf. WALKER, J. \& CHAPLIN, S. 2002. Una introducción a la cultura visual. Barcelona: Octaedro-EuB.

WARD, T. 2001. From the "People" to the "Nation": an emerging notion in Sahagún, Ixtlilxóchitl and Muñoz Camargo. Revista de Cultura Náhuatl 32: 223-234. México DF. 